Etnográfica

Revista do Centro em Rede de Investigação em

Antropologia

vol. $13(2) \mid 2009$

Vol. $13(2)$

\title{
Benoît de l'Estoile, Le goût des autres: de l'exposition coloniale aux arts premiers
}

Jean-Yves Durand

\section{(2) OpenEdition \\ Journals}

Edição electrónica

URL: https://journals.openedition.org/etnografica/1186

DOI: 10.4000/etnografica. 1186

ISSN: 2182-2891

\section{Editora}

Centro em Rede de Investigação em Antropologia

\section{Edição impressa}

Data de publição: 1 novembro 2009

Paginação: 491-493

ISSN: 0873-6561

\section{Refêrencia eletrónica}

Jean-Yves Durand, «Benoît de l'Estoile, Le goût des autres: de l'exposition coloniale aux arts premiers», Etnográfica [Online], vol. 13 (2) | 2009, posto online no dia 16 maio 2012, consultado o 12 fevereiro 2022. URL: http://journals.openedition.org/etnografica/1186 ; DOI: https://doi.org/10.4000/ etnografica. 1186

Etnográfica is licensed under a Creative Commons Attribution-NonCommercial 4.0 International License. 
dialéctica, que seja capaz de actualizar o diálogo relacional, justamente entre as famílias ciganas com as quais o antropólogo trabalhou e os espaços experienciais por elas vivenciados e construídos na contínua "negociação" social e cultural com o "mundo" dos não-ciganos. Embora relativa a um contexto histórico e cultural específico, o das famílias francesas manouches, a etnografia Nous, on n'en parle pas, de Patrick Williams (Ministère de la Culture et de la Francophonie/Maison des sciences de l'homme, 1993), ao analisar a dimensão do "silêncio" e do "rumor", e ao perguntar-se

Benoît de l'Estoile

LE GOÛT DES AUTRES:

DE L'EXPOSITION COLONIALE

AUX ARTS PREMIERS

Paris, Flammarion, 2007, 454 páginas.

Nos últimos vinte anos, a situação dos grandes museus etnográficos franceses alimentou acesos debates. O livro de Benoît de l'Estoile foi publicado um ano após a inauguração, em Junho de 2006, do Musée du Quai Branly, constituído a partir das colecções etnográficas exóticas do Musée de l'Homme. Numa língua sempre clara, integrando referências bibliográficas cosmopolitas, estas 454 páginas notavelmente documentadas incluem úteis índices de pessoas, de temas, de museus e exposições uma prática que ainda não é geral na edição francesa de ciências sociais; deplora-se, em contrapartida, a ausência de uma bibliografia recapitulativa. A partir das questões suscitadas pela elaboração do Musée du Quay Branly (nome ocultando a polémica designação inicial de Musée des Arts Premiers), se o advento e a adesão consistente dos manouches ao movimento pentecostal não terá intervindo na relação "silenciosa" entre manouches, oferece um ponto de vista interessante para a exploração de aspectos que talvez tenham sido menos aprofundados por Ruy Llera Blanes, como o da construção social do movimento religioso da Igreja de Filadélfia, que nos indica quão constitutivas do mesmo são as redes ciganas de pertença e sociabilidade familiar e parental.

\section{Micol Brazzabeni}

CRIA, bolseira FCT aborda-se problemas mais amplos: o sentido dos "museus dos Outros" no mundo pós-colonial; o museu enquanto catalisador de uma antropologia do "goût des Autres" (alusão a um filme de Agnès Jaoui centrado nas difíceis relações, no quotidiano, entre adeptos de gostos estéticos diferentes), das "nossas concepções da alteridade e das suas transformações” (p. 20). É de notar que, como o autor aliás admite, a dicotomia museu dos Outros/museu de Nós é demasiado esquemática, como se vê com o Museu Nacional de Etnologia de Lisboa.

Procurando um distanciamento, a análise procede por historicização e comparação. A primeira parte mostra como, entre as duas guerras mundiais, três tipos de discursos (evolucionista, diferencialista, primitivista) se entrelaçam, nomeadamente na Exposition Coloniale de 1931, resultando num universalismo plural consagrado em 1937 pela inauguração do Musée de l'Homme e o "triunfo da etnologia" enquanto detentora da autoridade científica sobre os objectos dos Outros. O projecto colonialista combina-se com um reconhecimento da diversidade 
cultural. E este tem por corolário a valorização estética da "arte negra". Esta forma do gosto dos Outros e a etnografia participam de um regime diferencialista de representação da alteridade, no qual se enraiza o Musée du Quai Branly, em continuidade com o contexto que informou a criação do Musée de l'Homme. Mas Benoît de l'Estoile mostra como este não soube evoluir: diluição da articulação entre antropologia física e etnografia; imobilismo resultando em óbvias divergências entre as exposições e as realidades que supostamente representariam e sobre as quais o público se tornava cada vez mais informado. O regresso a uma estratégia de reconstituição "realista" (que tinha sido inicialmente rejeitada) e a uma ilusão de "viagem" indica a incapacidade de transmitir um discurso antropológico. Chega-se a um "contra-senso anacrónico" (p. 204) usado como argumento pelos promotores de uma museografia estética.

O olhar alarga-se na segunda parte além do caso francês, para melhor salientar a sua especificidade. Uma história dos museus dos Outros e uma perspectiva comparativa mostram até que ponto a actual requalificação dos museus dos Outros em museus das artes dos Outros ou "das culturas do mundo", reforçada pela crise pós-colonial da representação etnográfica, assenta naquilo a que o autor chama "mitos contemporâneos": as "artes primeiras" e os "povos primeiros". Promovida por coleccionadores, a primeira noção é uma reformulação do primitivismo. Dá a ilusão de uma ruptura com o evolucionismo e permite conciliar uma atitude de reconhecimento dos Outros com o prazer do amador de arte, a ética com o mercado. Supondo a existência de uma estética universal e mesmo a-histórica, a noção permite uma abordagem descontextualizada dos objectos, transformados em "obras", tomados unicamente como vectores de deleite estético. A antropologia perde o seu monopólio interpretativo e passa a ter no museu um papel marginal, incapaz de vulgarizar a desconstrução do essencialismo primitivista, da ideia de "povos primeiros" que teriam ficado "autênticos". Benoît de l'Estoile mostra como o programa arquitectónico do Musée do Quai Branly, da autoria de Jean Nouvel, é a materialização de um "mito" hoje muito divulgado nos discursos que aliam de maneira confusa preocupações ecológicas, busca de uma sabedoria tradicional, defesa da diversidade cultural. O novo museu confronta-se com o risco de ser visto como a evocação nostálgica de mundos perdidos.

De todas as maneiras, não pode evitar os paradoxos e as contradições hoje inerentes a qualquer projecto etnomuseológico. A questão dos direitos de propriedade (e de discurso) sobre os objectos e os saberes dos Outros e as suas articulações com as implicações éticas e políticas do essencialismo estratégico já são muito debatidas em antropologia. A partir de uma eficaz síntese do assunto (capítulo Ix), Benoît de l'Estoile prossegue com uma reflexão acerca da possível evolução dos museus dos Outros e dos museus identitários para museus centrados nas relações entre Nós e os Outros, recusando “a percepção em termos arqueológicos de sociedades vivas" (p. 383), feitas de processos. Especulativos, apresentando experimentações museológicas recentes, enriquecidos por uma experiência pessoal de elaboração de uma exposição, os últimos dois capítulos são estimulantes.

Como sempre sucede com uma obra inspiradora, são as suas qualidades que salientam os seus limites. As questões levantadas são tantas e as suas implicações tão complexas que, apesar das advertências do autor, ciente da impossibilidade de esgotar o assunto, o leitor só pode desejar mais. $\mathrm{O}$ recurso pertinente a um caderno de imagens que sintetizam o argumento e ilustram a evolução da "mise en forme" museológica implementada nos museus dos Outros faz 
sentir, por exemplo, o potencial de uma análise visual do manancial iconográfico que não foi possível reproduzir. Entre os documentos apresentados, um cartaz inspirado numa capa de Tintim: como admite o autor, um museu é, obviamente, também sustentado por "representações colectivas” (p. 20). Como vimos, o considerável sucesso público do Musée du Quai Branly vai muito além do "efeito arquitecto" que dá visibilidade internacional a museus recentes (como o Guggenheim de Bilbao): a força das representações primitivistas e essencialistas no gosto dos Outros hoje vigente tem um papel indubitável no regresso dos parisienses ao museu etnográfico. Desde logo, será que o eventual interesse de um largo público por uma museologia que foca os processos e a interlocução é mais do que wishful thinking? A convocação final da fraca metáfora da tradução cultural, chavão já algo gasto, não ajuda a ficar convencido do contrário.

Será preciso, também, mais etnografia para o saber. As relevantes vinhetas que relançam constantemente a análise levam a desejar uma continuação da observação: concluído quando o Musée do Quai Branly ainda era só uma casca vazia, o livro não examina o seu público, nem as suas exposições temporárias. Os defensores do novo museu insistem na necessidade de o considerar como um todo que integra exposições permanentes e temporárias, conferências, mediateca, concertos, etc.: um verdadeiro projecto cultural. Ao fim de alguns anos, será que a interlocução, o diálogo intercultural, acontece? Qual é o papel do museu na mercadorização da cultura, incluindo no mercado das artes exóticas? O que significa o facto de ser escolhido para a organização de numerosos "eventos" de prestígio? De um ponto de vista mais geral, onde (se é que algures) colocar agora o limite entre museologia, intervenção cultural e espectáculo?

Pela sua riqueza informativa, a sistematização dos problemas que levanta, o rigor do seu raciocínio, as suas propostas sugestivas, Le Goût des Autres constitui uma leitura indispensável para quem se vê envolvido numa situação de patrimonialização ou se pergunta o que fazer com os museus etnográficos, de todos os tamanhos e todos os feitios. Em Portugal também, tentativas de resposta são urgentes.

\section{Jean-Yves Durand \\ CRIA-UM}

